\title{
The Influence of Lecturer Competence, Self-Efficacy and Motivation on Student Achievement of the Faculty of Economics and Business, Warmadewa University
}

\author{
AA Media Martadiani $\#^{1}$, Ita Silvia Azita Aziz $\#^{2}$, Dewa Ayu Niti Widari $\#^{3}$ \\ ${ }^{\#}$ Faculty of Economics and Business, Warmadewa University, Denpasar, Bali-Indonesia
}

\begin{abstract}
This study aims to analyze the mediating role of self-efficacy and motivation between lecturer competencies, on student achievement in the Faculty of Economics and Business, Warmadewa University. The sample used in this study were 93 students. Research resultshows that all variables have a positive and significant effect on student achievement. Self efficacy and motivation fully mediate between lecturer competence and student achievement.
\end{abstract}

Keywords--- Lecture Competence, Self-Efficacy, Motivation, Learning Achievement

\section{INTRODUCTION}

The era of disruptive innovation requires universities to open e-learning courses. Minister of Research Technology and Higher Education (Menristekdikti) Mohamamd Nasir said "e-learning learning systems must be balanced with increasing lecturer competence. The students faced by lecturers today are millennial generation and generation $\mathrm{Z}$ students. Therefore, lecturers must improve scientific competence and innovate learning methods. With or without distance education, the role and how lecturers should be is trying to always be creative by not only fixating on curriculum achievement and giving assignments. Therefore, the creativity of lecturers in mastering innovative learning material technology is highly expected, which is also tested in online learning situations like today.

Where the principles of the modern learning model must be in harmony with the four pillars of education compiled by Unesco, namely: learning to know (learning to know), learning to do (learning to do something), learning to be (learning to be something), and learning to be. to live together (learn to live together). This is when the lecturers have to go back to teaching how to learn (learning how to learn), not learning about something (learning what to learn). The current demand for educational outcomes, students must have $21 \mathrm{st}$ century skills (character, literacy principles, and 4C competencies: Critical Thinking, Creative, Communication, Collaborative), then lecturers must begin to change their paradigm to be more critical thinking, open and continuously growing so that it can be relied upon to meet the demands of the times that require an increase in the quality of education In addition to the influence of lecturer competence, which includes: knowledge (skills,) ability and attitude, self-efficacy, the motivation of the student concerned also determines the performance of a student. Research conducted by [1] and [2] shows that individuals who have strong self-efficacy see their failure as a factor of lack of effort (lack of effort), thus motivating them to work hard to improve their failure. On the other hand, individuals who have low self-efficacy see their failure due to a lack of self-efficacy (lack of ability), thus making their motivation decrease [3]. Most of the assessments (student performance) are based solely on the achievement index (IP), which is a formal assessment of the institution, even though IP does not describe the actual performance of students. For this reason, student performance assessment should not only be based on the final output, but also during the learning process because it occurs over a certain period of time and includes various assessments of assignments given to students in accordance with the existing educational taxonomy.

The phenomenon revealed from observations and interviews is that many students simply do not attend lectures on the grounds that the lecturers who teach the courses are less competent. Based on the description 
DOI: $10.51386 / 25815946 / \mathrm{ijsms}-\mathrm{v} 4 \mathrm{i} 4 \mathrm{p} 106$

above, it can be seen that lecturer competence, self-efficacy and motivation play an important role in the entire teaching and learning process, so that the increase in lecturer competence, self-confidence and student motivation is expected to be able to improve student achievement which is generally measured based on the cumulative achievement index

\section{II.THEOROTICAL REVIEW}

\section{THEORY OF PLANNED BEHAVIOR}

[4] is a further development of the Theory of Reasoned Action. The theory of planned behavior is a theory about the relationship between beliefs and behavior. This theory states that attitudes toward behavior, subjective norms, and perceptions of behavioral control, together form an individual's behavioral intentions and behaviors.

\section{COMPETENCE}

Competence is a description of the main skills, knowledge, abilities and attitudes needed to achieve effective performance in work [5]. According to Lawler in [6], competence is the capacity of organisms to interact effectively with the environment. [7] asserted that HR competencies are divided into two, namely those that are visible, such as knowledge competence and skill competencies, and invisible competencies (hidden competencies) such as self-concepts, traits and motives that are visible. all of them belong to the attitude category. [15], found that that subject knowledge, teaching skills, lecturer attendance, and the attitude of the lecturer has a significant positive effect on students' academic achievement. According to [16] in Nigeria, with 300 teachers as respondents it shows that effective teachers produce students who perform better., [16], and [17] showed the same thing that the competence of lecturers (teachers) had a significant impact on student academic achievement.[19] who conducted research in Uganda. High teacher competence affects students' high academic achievement in reading and arithmetic.

So comprehensively, competence can be concluded that HR competence consists of 4 variables, namely (1) knowledge-knowledge, (2) ability-knowledge, (3) skills, expertise, (4) attitude (attitude). These four competency variables are integrated in a model called the HR Competency Model. Which is a model for implementing the four competency variables effectively and efficiently. From the various theoretical explanations above, a model of HR competence is drawn up which can be seen clearly in Figure 1 below.

\section{SELF CONFIDENCE}

In addition to the competence of the teacher, the self-efficacy of the student concerned also plays an important role in achieving high performance. [8] Define self-confidence as an individual's belief in his ability to perform certain tasks successfully. Meanwhile, Albert [9], mentions self-confidence as personnel judgment or belief about how well a person can carry out certain desired activities related to future situations. [10] suggest that self-efficacy has 3 basic components (dimensions): 1) Mangnitude (task difficulty level), 2) That is applying the level of task difficulty that a person believes he or she can achieve, 3) Strength (resistance). That is the strength or weakness of a person's belief in achieving difficult tasks (measures whether the magnitude is strong or weak. The strength dimension relates to the strength of judgments about individual abilities and refers to the degree of individual stability to the beliefs or expectations he makes.

\section{MOTIVATION TO LEARN}

Motivation is related to learning activities, because in learning motivation is needed. This is confirmed by [11] that motivation "is an essential condition of learning". Learning outcomes will be optimal if there is motivation. [12] Describes learning motivation as a tendency for students to find meaning in academic activities and try to find out what results can be obtained from these academic activities.

\section{LEARNING ACHIEVEMENT}

Learning achievement according to [13] which states that learning achievement is a proof of learning success or a student's ability to carry out learning activities according to the weight he has achieved. Meanwhile, according to [14], achievement or learning outcomes (achievement) is the realization of Potential skills or capacities possessed by a person/mastery of learning outcomes can be seen from his behavior, both behavior in the form of mastery, knowledge, thinking skills and motor skills.On campus learning outcomes or learning achievements can be seen from students' mastery of courses that have been taken. he took. The tool to measure learning achievement/outcome is called a learning achievement test or achievement test compiled by the lecturer who teaches the subject in question. 


\section{CONCEPTUAL FRAMEWORK}

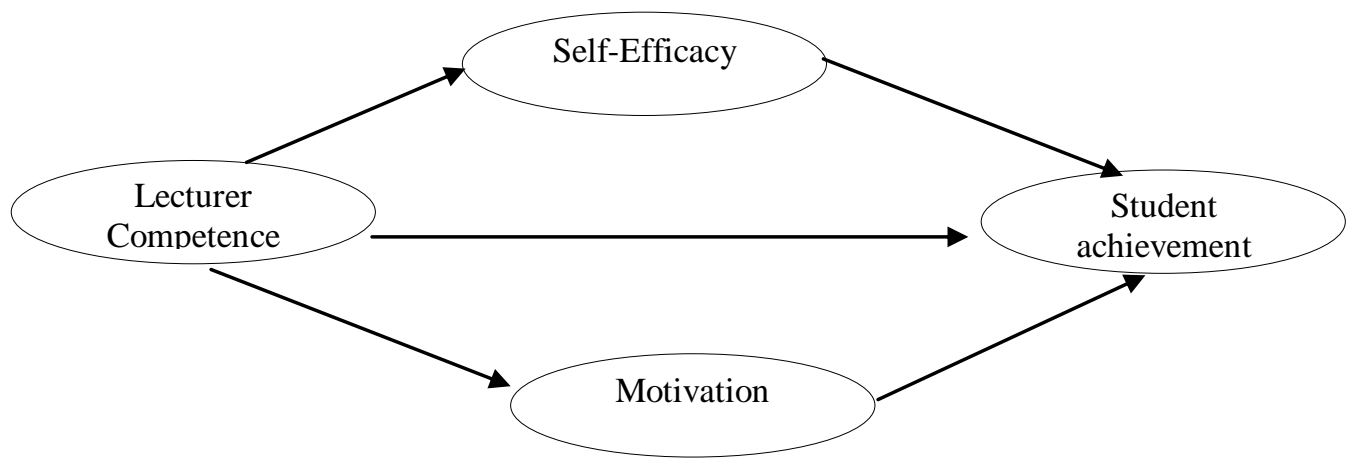

\section{HYPOTHESIS}

Figure 1. Framework

Based on theoretical studies and the results of previous studies, the hypotheses proposed in this study are as follows:

H1: Lecturer competence has an effect on Self Efficacy from students,

H2 : Self Efficacy affect student achievement

H3: Lecturer competence has an effect on student achievement.

H4: Lecturer competence has an effect on student motivation.

H5: Motivation has an effect on student achievement.

H6 : Lecturer competence has an indirect effect on student achievement through Self Efficacy.

H7: Lecturer competence has an indirect effect on student achievement through motivation

\section{METHOD}

This research is an explanatory research that is testing hypotheses between variables and is centered on the explanation of the relationships between variables. The location of the research was carried out at the FEB of Warmadewa University, using a saturated sample obtained 93 students as respondents. All questionnaires returned intact and can be processed and analyzed further. Collecting data using a questionnaire using a five point Likert. In this study, data analysis used the Partial Least Square (PLS) approach with the help of Smart PLS 3.2.9 software. SEM-PLS is a component-based structural equation model which is more predictive. PLS is a powerful analytical method, because it is not based on many assumptions (Ghozali., 2021).

\section{IV.RESULTS AND DISCUSSION}

\section{DATA ANALYSIS}

In this study, inferential analysis was measured using Smart PLS software version 3.2.9, starting from measuring data quality [outer model], model structure [inner model] and hypothesis testing. The results obtained from several tests are shown in Table 1 and Figure 2 which show that all indicators have met the requirements, because the indicator has an outer loading above 0.5 and this already has convergent validity so that the model is feasible for further analysis.

TABLE I.

FACTOR LOADING

\begin{tabular}{|c|c|c|c|c|}
\hline & Lecturer Competence & Motivation & Student Achievment & Self-Efficacy \\
\hline M1.8 & & & & 1,000 \\
\hline M2.2 & & 0,912 & & \\
\hline $\mathrm{M} 2.5$ & & 0,835 & & \\
\hline $\mathrm{X} 1.1$ & 0,813 & & & \\
\hline $\mathrm{X} 1.10$ & 0,772 & & & \\
\hline $\mathrm{X} 1.8$ & 0,790 & & & \\
\hline Y.2 & & & 1,000 & \\
\hline
\end{tabular}




\section{Data QuALiTy}

After seeing the value of the loading factor and meeting the feasibility, then look at the results of testing data quality. The results obtained in data quality testing are used outer model analysis to specify the relationship between latent variables and their indicators or it can be said that this defines how each indicator relates to its latent variables. The following is a summary of the results of the outer model testing which includes discriminant validity, composite reliability and Cronbach alpha.

TABLE II

ROLE OF THUMBS OUTER MODEL SUMMARY

\begin{tabular}{|c|c|c|c|c|c|}
\hline Validity and Reliability & Parameter & Construct & Results & Criteria & Information \\
\hline \multirow{9}{*}{ Concergent Validity } & \multicolumn{2}{|l|}{ Loading Factor } & $0.772-1,000$ &.$>0.60$ & Accepted \\
\hline & \multirow{4}{*}{$\begin{array}{l}\text { Average Variance } \\
\text { Extracted [AVE] }\end{array}$} & Lecturer Competence & 0.627 &.$>0.50$ & Accepted \\
\hline & & \begin{tabular}{l|} 
Motivation \\
\end{tabular} & 0.764 &.$>0.50$ & Accepted \\
\hline & & Student Achievement & 1,000 &.$>0.50$ & Accepted \\
\hline & & Self Efficacy & 1,000 &.$>0.50$ & Accepted \\
\hline & \multirow{4}{*}{ Communality } & Lecturer Competence & 0.706 & $>0.50$ & Accepted \\
\hline & & Motivation & 0.738 & $>0.50$ & Accepted \\
\hline & & Student Achievement & 1,000 & $>0.50$ & Accepted \\
\hline & & Self Efficacy & 1,000 & $>0.50$ & Accepted \\
\hline \multirow{3}{*}{ Discriminant Validity } & \multicolumn{2}{|l|}{ Cross Loading } & $-0.016-1,000$ &.$>0.60$ & Accepted \\
\hline & \multicolumn{2}{|c|}{$\begin{array}{l}\text { Square root of AVE Greater correlation } \\
\text { between Latent constructs }\end{array}$} & $0.792-1,000$ & $0.212-0.606$ & Accepted \\
\hline & \multicolumn{2}{|c|}{ Heterotrait-Monotrait Ratio [HTMT] } & $0.085-0.706$ & $<0.90$ & Accepted \\
\hline \multirow{8}{*}{ Reliability } & \multirow{4}{*}{ Cronbrach Alpha } & Lecturer Competence & 0.704 &.$>0.60$ & Accepted \\
\hline & & Motivation & 0.697 &.$>0.60$ & Accepted \\
\hline & & Student Achievement & 1,000 &.$>0.60$ & Accepted \\
\hline & & Self Efficacy & 1,000 &.$>0.60$ & Accepted \\
\hline & \multirow{4}{*}{$\begin{array}{l}\text { Composite } \\
\text { Reliability }\end{array}$} & Lecturer Competence & 0.834 &.$>0.60$ & Accepted \\
\hline & & Motivation & 0.866 &.$>0.60$ & Accepted \\
\hline & & Student Achievement & 1,000 &.$>0.60$ & Accepted \\
\hline & & Self Efficacy & 1,000 &.$>0.60$ & Accepted \\
\hline
\end{tabular}

3. Model Structure Test Results

The results obtained in testing the structure of the model used inner model analysis. This describes the relationship between latent variables based on substantive theory. The following is a summary of the results of testing the structural model which includes R square and $f$ square.

TABLE III

SUMMARY OF THE ROLE OF THUMBS STRUCTURAL MODEL

\begin{tabular}{|l|l|l|l|l|}
\hline Parameter & Construct & Results & Criteria & Information \\
\hline R square & 0.176 & $\begin{array}{l}0.19 \text { Weak } \\
0.33 \text { Moderate } \\
0.67 \text { Strong }\end{array}$ & Weak Model \\
\hline Effect size & Lecturer & 0.000 & $\begin{array}{l}0.02 \text { Small } \\
0.15 \text { Medium } \\
0.33 \text { Big }\end{array}$ & Small Influence \\
& Competence & & $\begin{array}{l}0.02 \text { Small } \\
0.15 \text { Medium } \\
0.33 \text { Big }\end{array}$ & Small Influence \\
& Motivation & 0.026 & & \\
& & &
\end{tabular}




\begin{tabular}{|l|l|l|l|l|}
\hline & Self-Efficacy & 0.178 & $\begin{array}{l}0.02 \text { Small } \\
0.15 \text { Medium } \\
0.33 \mathrm{Big}\end{array}$ & $\begin{array}{l}\text { Medium Influence } \\
\text { Pengaruh }\end{array}$ \\
\hline
\end{tabular}

\section{HyPOTHESIS TEST RESULTS}

In testing the hypothesis, the results of the correlation between constructs are measured by looking at the path coefficients and their level of significance which are then equated with the research hypotheses contained in the previous chapter. The following table shows the results of hypothesis testing based on PLS bootstrapping.

TABLE IV

SUMMARY OF DiRECT EFFECT TEST RESULTS

\begin{tabular}{|l|r|r|r|r|}
\hline $\begin{array}{l}\text { The direction of the relationship between } \\
\text { constructs }\end{array}$ & $\begin{array}{c}\text { Original } \\
\text { Sample (O) }\end{array}$ & $\begin{array}{c}\text { T Statistics } \\
(|\mathrm{O} / \mathrm{STDEV}|)\end{array}$ & P Values & Information \\
\hline Lecturer Competence -> Self Efficacy & 0.587 & 10,665 & 0.000 & Significant \\
\hline Lecturer Competence -> Motivation & 0.621 & 10,280 & 0.000 & Significant \\
\hline $\begin{array}{l}\text { Lecturer Competence -> Student } \\
\text { Achievement }\end{array}$ & 0.215 & 2,983 & 0.003 & Significant \\
\hline Motivation -> Student Achievement & 0.655 & 10.939 & 0.000 & Significant \\
\hline Self Efficacy -> Student Achievement & 0.133 & 2,132 & 0.034 & Significant \\
\hline
\end{tabular}

\section{DISCUSSION}

1. The Influence of Lecturer Competence on Self Efficacy

Provide information that Lecturer Competence shows a positive and significant influence on self-efficacy, where the path coefficient shown is 0.587 with t-statistics $10,665>$ from 1.96 . The results of this test indicate that Hypothesis 1 (H1) is accepted. This states that the better the competence of the lecturer, the self-efficacy will increase. The results of this study are supported by Permatasari, (2007) also found that the competence of lecturers has a positive and significant effect on self-efficacy.

2. Influence Lecturer Competence on motivation

Provide information that lecturer competence shows a positive and significant influence on motivation, where the path coefficient shown is 0.621 with t-statistics $10,280>$ from 1.96 . The results of this test indicate that Hypothesis $2(\mathrm{H} 2)$ is accepted. This means that the better the competence of the lecturer, the motivation will increase. The results of this study are supported by Alam Yuki (2017) who finds that lecturer competence has a positive and significant effect on motivation. The same result is shown by Tahrir (2013). Lecturer competence has a positive and significant effect on student learning motivation motivasi.

3. The Influence of Lecturer Competence on Student Achievement

Provide information that the competence of lecturers shows a positive and significant influence on student achievement, where the path coefficient shown is 0.215 with t-statistics $2,983>$ from 1.96 . The results of this test indicate that Hypothesis $3(\mathrm{H} 3)$ is accepted. This means that the better the competence of the lecturer, the student's achievement will increase. This research is supported by Ridwan (2019 lecturer competence has a positive or significant effect on academic achievement).

\section{The Effect of Motivation on Student Achievement}

Provide information that motivation shows a positive and significant influence on student achievement, where the path coefficient shown is 0.655 with t-statistics $10.939>$ from 1.96 . The results of this test indicate that Hypothesis $4(\mathrm{H} 4)$ is accepted. This means that the better the competence of the lecturer, the student's achievement will increase. This research is supported by Wijaya 2018, stating that student learning motivation has a significant positive effect on student learning achievement.

5. The Influence of Self Efficacy on Student Achievement

Provide information that motivation shows a positive and significant influence on student achievement, 
where the path coefficient shown is 0.133 with t-statistics $2,132>$ from 1.96 . The results of this test indicate that Hypothesis 5(H5) is accepted. This states that the better the competence of the lecturer, the student's achievement will increase.

6. Indirect influence testing/Mediation Test.

The mediating effect shows the relationship between the independent and dependent variables through the connecting variable or mediation. The effect of the variable on the dependent variable does not occur directly but through a transformation process represented by the mediating variable. This study uses the Variance Accounted For (VAF) method and bootstrapping in the distribution of indirect effects is considered more appropriate because it does not require any assumptions about the distribution of variables so that it can be applied to a small sample size. This approach is most appropriate for PLS which uses the resampling method and has higher statistical power than the Sobel method.

Test Procedure Steps, 1) The first step in the mediation testing procedure is that the direct effect of the independent variable on the dependent variable must be significant, 2) Second, the indirect effect must be significant, each path, namely the independent variable on the mediating variable and the mediating variable on the dependent variable, must be significant to fulfill this condition. This indirect effect is obtained by the formula for the effect of the independent variable on the mediating variable multiplied by the effect of the mediating variable on the dependent variable (Sholihin, 2014). If the indirect effect is significant, then this indicates that the mediating variable is able to absorb or reduce the direct effect in the first test, 3) Third, calculate VAF with the following formula:

$$
V A F=\frac{\text { Pengaruh Tidak Langsung }}{\text { pengaruh langsung }+ \text { pengaruh tidak langsung }}
$$

If the VAF value is above $80 \%$, it shows the role of $\mathrm{Z} 1$ and $\mathrm{Z} 2$ as full mediation. $\mathrm{Z} 1$ and $\mathrm{Z} 2$ are categorized as partial mediators if the VAF value ranges from $20 \%$ to $80 \%$, but if the VAF value is less than $20 \%$ it can be concluded that there is almost no mediating effect. Based on Table 7, it has been proven that the results of the direct influence test of this research model are significant so that an indirect effect test can be carried out. The variables of self-efficacy and motivation are included in the research model as mediating variables.

TABLE IV

Calculation of VAF

\begin{tabular}{|c|l|c|}
\hline & \multicolumn{1}{|c|}{ Direct Influence } & Coef. \\
\hline 1 & Lecturer Competence -> Self Efficacy & 0.587 \\
\hline 2 & Self Efficacy -> Student Achievement & 0.133 \\
\hline 3 & Lecturer Competence -> Student Achievement & 0.215 \\
\hline 4 & Lecturer Competence -> Motivation & 0.621 \\
\hline 5 & Motivation -> Student Achievement & 0.655 \\
\hline & \multicolumn{1}{|c}{ Indirect Influence } & 0.078 \\
\hline 1 & Lecturer Competence -> Self Efficacy -> Student Achievement & 0.407 \\
\hline 2 & Lecturer Competence -> Motivation -> Student Achievement & \\
\hline
\end{tabular}

Based on the calculation of the VAF to test the effect of self-efficacy and motivation variables as a mediator between the influence of lecturer competence on academic achievement, it is 0.849 or $84.9 \%$. From these results it can be concluded that self-efficacy and motivation have a full mediation effect.

\section{Research Findings}

Self Efficacy turns out to be able to perfectly mediate the relationship between Lecturer Competence and Student Learning Achievement, this can be reflected that increasing lecturer competence is able to improve student learning achievement by increasing self-efficacy and motivation turns out to be able to perfectly mediate the relationship between Lecturer Competence and Student Learning Achievement, it can be reflected that increasing Lecturer Competence is able to improve Student Learning Achievement by increasing student motivation. 


\section{CONCLUSIONS AND SUGGESTIONS}

Lecturer competence has a positive and significant effect on student self-efficacy, which means that an increase in lecturer competence will be followed by an increase in student self-efficacy. Self efficacy positive and significant effect on student achievement, which means an increase in self efficacy is followed by an increase in student achievement. Lecturer competence has a positive and significant effect on student achievement, this shows that the higher the competence of the lecturer, the student's achievement will increase. Lecturer competence has a positive and significant effect on student motivation, if you want to increase student learning motivation, then lecturer competence needs to be improved first. Motivation has a positive and significant effect on student achievement, which means an increase in motivation will increase student achievement. Self efficacy mediate perfectly / full mediation, the influence of lecturer competence on student achievement. This shows that if you want to improve student achievement, you must increase the student's selfefficacy. Motivation to mediate perfectly / full mediation, the influence of lecturer competence on student achievement. This shows that if you want to improve student achievement, you must increase the motivation of the students concerned.

Suggestions, For leaders of the Faculty of Economics and Business, University of Warmadewa, if they want to improve student achievement, they should pay attention to increasing student motivation and selfefficacy. It is necessary to extract in-depth information about learning motivation and how much student selfefficacy is to succeed in participating in the recovery of the Faculty of Economics and Business, University of Warmadewa. Increasing the quality of lecturers, especially in research and scientific publications, should be prioritized by the FEB leadership so that the quality of lecturers in real terms increases. For other researchers, they should develop other variables outside the model in this study and increase the range of research from other faculties at Warmadewa University and be equipped with a qualitative approach in order to obtain a more comprehensive picture of the teaching and learning process at Warmadewa University.

\section{BIBLIOGRAPHY}

[1] A. Bandura, "Self-efficacy: Toward a Unifying Theory of Behavioral Change," vol. 84, no. 2, pp. 191-215, 1977.

[2] P. Peura et al., "Trajectories of change in reading self-efficacy: A longitudinal analysis of self-efficacy and its sources," Contemp. Educ. Psychol., vol. 64, 2021, doi: 10.1016/j.cedpsych.2021.101947.

[3] J. W. Santrock, Educational psychology, 6th ed. 2018.

[4] I. Ajzen, "The theory of planned behavior: Frequently asked questions," Hum. Behav. Emerg. Technol., vol. 2, no. 4, 2020, doi: $10.1002 / \mathrm{hbe} 2.195$

[5] M. S. Taat, K. Abdulbaki, and A. Al-Saqqaf, "The Impact of Lecture and Interactive Methods onStudent's English Competency," Int. J. Emerg. Technol. Learn., vol. 15, no. 20, 2020, doi: 10.3991/ijet.v15i20.16683.

[6] S. Greenspan and G. Woods, "Social Incompetence of FASD Offenders: Risk-Awareness as a Factor in Criminal Culpability," 2018.

[7] G. Selcuk, S. Aydin, and A. Cakmak, "Examining beliefs of preservice teachers about self-competency and lifelong learning competency via canonical correlation analysis," in Cypriot Journal of Educational Sciences, 2018, vol. 13, no. 2, doi: 10.18844/cjes.v13i2.3232.

[8] L. K. Treviño, N. A. Den Nieuwenboer, and J. J. Kish-Gephart, "Unethical behavior in organizations," Annual Review of Psychology, vol. 65. 2014, doi: 10.1146/annurev-psych-113011-143745.

[9] T. L. Pakpahan, "Manfaat Jahe (Zingiber officinale Roscoe) terhadap Kadar Asam Urat," J. Agromedicine, vol. 2, no. 4, pp. 530-535, 2015, [Online]. Available: http://juke.kedokteran.unila.ac.id/index.php/agro/article/view/1250/pdf.

[10] V. Sesari Adyagarini, Afifudin, and Hariri, "Pengaruh Motivasi, Selff Efficacy, Dan Pemahaman Pada Peraturan Menteri Keuangan No. 111/PMK.03/2014 Terhadap Minat Berkarir Mahasiswa Akuntansi Sebagai Konsultan Pajak,” E-Jra, vol. 09, no. 02, 2020.

[11] F. Tentama, Subardjo, and M. H. Abdillah, "Motivation to learn and social support determine employability among vocational high school students,” Int. J. Eval. Res. Educ., vol. 8, no. 2, 2019, doi: 10.11591/ijere.v8i2.18188.

[12] B. M. Walsh and V. J. Magley, "Workplace civility training: understanding drivers of motivation to learn," Int. J. Hum. Resour. Manag., vol. 31, no. 17, 2020, doi: 10.1080/09585192.2018.1441164.

[13] I. G. Margunayasa, N. Dantes, A. A. I. N. Marhaeni, and I. W. Suastra, "The effect of guided inquiry learning and cognitive style on science learning achievement," Int. J. Instr., vol. 12, no. 1, 2019, doi: 10.29333/iji.2019.12147a.

[14] F. Harahap, N. E. A. Nasution, and B. Manurung, "The effect of blended learning on student's learning achievement and science process skills in plant tissue culture course," Int. J. Instr., vol. 12, no. 1, 2019, doi: 10.29333/iji.2019.12134a. 
DOI: $10.51386 / 25815946 / \mathrm{ijsms}-\mathrm{v} 4 \mathrm{i} 4 \mathrm{p} 106$

Volume: 4 Issue: 4

[15] L. N. \& D. Setiyaningsih, "Pengaruh Kompetensi Pedagogik \& Motivasi Terhadap Efikasi Diri Guru Sdn Gugus Vi Palmerah Jakarta Barat," HOLISTIKA J. Ilm. PGSD, vol. IV, pp. 45-52, 2020

[16] R. W. Murti and A. P. Prasetio, "Pengaruh Kompetensi Dosen terhadap Prestasi Akademik Mahasiswa Fakultas Ekonomi dan Bisnis Telkom University,” J. Penelit. Pendidik., vol. 18, no. 2, 2018, doi: 10.17509/jpp.v18i2.12950.

[17] W. Indianto, D. H. Anriva, and W. laura Hardilawati, "The Influence of emotional intelligence, learning facilities, and lecturer competences on academic achievement of accounting students," J. Akunt. dan Ekon., vol. 10, no. 2, 2020, doi: $10.37859 /$ jae.v10i2.2345.

[18] P. H. P. Wahyudi and M. M. Ratna Sari, "Pengaruh Kecerdasan Emosional, Fasilitas Belajar dan Kompetensi Dosen Terhadap Persepsi Prestasi Akademik Mahasiswa Akuntansi," E-Jurnal Akunt., vol. 29, no. 3, 2019, doi: 10.24843/eja.2019.v29.i03.p13.

[19] M. Y. Amrullah and A. H. DS, "Pengaruh Kompetensi Dan Kompensasi Terhadap Motivasi Kerja Karyawan Di Divisi Body \& Rangka Cv. Laksana,” Diponegoro J. Soc. Polit., pp. 1-7, 2018. 